\title{
E. González Cárdenas, E. Escobar Lahoz, R. Becerra Ramírez, R.U. Gosálvez Rey, J. Dóniz Páez (eds): Aportaciones Recientes en Volcanología 2005-2008
}

\author{
Centro de Estudios Calatravos, UCLM, Ministerio de Ciencia y Tecnología, 2010. 412 pp, \\ ISBN: 978-84-614-1025-5, 39.94 Euro \\ [http://www.libreriaproteo.com/libro-578456-APORTACIONES-RECIENTES-EN- \\ VOLCANOLOGÍA-20052008.html]
}

\section{Corina Risso}

Accepted: 27 March 2011 / Published online: 28 April 2011

(C) Springer-Verlag 2011

This book in Spanish, the title of which translates to "Recent Contributions in Volcanology: 2005-2008", publishes the contributions from the 4th Meeting of the Spanish Volcanology Network. It is excellently presented and designed with many beautiful colour figures and photographs, and printed on high quality paper.

The first and last chapters deal with the past and the future, respectively, of Volcanology in Spain. The ironic style of Vicente Araña Saavedra makes the historical chapter an especially good read. The book is divided into six sections, with a prologue and an epilogue. There are a total of 59 papers in sections with titles translating as: 1.Introduction (2 papers) 2.- Volcanic Research in Spain: Peninsular volcanism (13 papers). 3.- Volcanic Research in Spain: The Canary Islands (13 papers) 4.- Geological and Geotechnical Risk in volcanic terrains (5 papers) 5.Volcanic Risk (11 papers) 6.- Volcanoes, Natural Resources and Environment (15 papers).

The chapters on Volcanic Geology of the Iberian Peninsula, particularly in Campo de Calatrava, are predominantly descriptive in nature. However, the work is

Editorial responsibility: K. Németh

\section{Risso $(\square)$}

Facultad de Ciencias Exactas y Naturales,

Departamento de Ciencias Geológicas,

Universidad de Buenos Aires,

Buenos Aires, Argentina

e-mail: rissocorina1@gmail.com laudable in respect of its contribution to the conservation of the pyroclastic edifices in this region, which are under threat of disappearance due to mining activity.

The study of volcanism in the Canary Islands experienced after the seismo-volcanic crisis of 2004 a great advance, which is reflected in the high quantity of papers presented in this book. Particularly interesting and very detailed are the papers on volcanic landslides, the dating and classification of monogenetic volcanoes on Tenerife, and the geodynamics of fumaroles of the Teide volcano. Without doubt the highlight is the presentation of extensive and excellent work on $\mathrm{CO}_{2}$ measurement in the Peninsula, the Canary Islands and around the world.

The last sections of the book are also very interesting, with articles on such subjects as the geotechnical aspects of volcanic materials that led to the publication of the Planning Guide for Construction in the Canary Islands, and the paper about the Volcanic Early Warning System. For non-biologists the section on the Flora and Fauna of the Canaries is not to be missed, and I learnt a great deal from it.

Altogether the papers, some more solid than others, give us an idea of the current volcanological knowledge in the Iberian Peninsula and the Canary Islands as produced by Spanish research groups. They contain much information of interest to Spanish and Spanish-speaking colleagues, and extensive bibliographies of Spanish-language publications that provide an excellent gateway to literature that non-Spanish volcanologists may otherwise miss out on. 